\title{
ACKNOW LEDGMENTS
}

It is with great pleasure and relief that I am finally able to thank the many people and institutions that have helped bring this book to the finish line. I want to start by thanking my teachers at the University of Chicago, where the book got its start. Thomas Holt taught me about the ways racism has operated in the modern world, and his commitment to deconstruct its corrosive logic has inspired many of the themes taken up by this book. From almost the very beginning, Bruce Cumings believed that I had something important to say. His faith has emboldened me to pose big questions and take chances with my writing. Kathleen Conzen patiently introduced a neophyte to the history of the North American West. Michael Geyer and Saskia Sassen taught me a great deal about the historicity and logic of globalization that have profoundly shaped my understanding about the development of the modern world. The camaraderie of Ellen Wu, Arissa Oh, Meredith Oda, Quincy Mills, Allyson Hobbs, Jason McGraw, and Albert Park who became friends and interlocutors enriched my Chicago experience.

From Chicago, I was fortunate to land at the University of Connecticut, where I found supportive colleagues in Shirley Roe, Frank Costigliola, Charles Lansing, Christopher Clark, Jeffrey Ogbar, Brendan Kane, Alexis Dudden, Nancy Shoemaker, Nina Dayton, Emma Gilligan, Melina Pappademos, Blanca Silvestrini, Cathy Schlund-Vials, Roger Buckley, Bandana Purkayastha, and Margo Machida. I want to especially thank Mark Overmyer-Velazquez who took a newly minted $\mathrm{PhD}$ under his wings and showed him the proverbial ropes. My current colleagues at RutgersNewark have contributed to the book in countless ways: Beryl Satter, James Goodman, Jan Ellen Lewis, Timothy-Stewart Winter, Ruth Feldstein, Susan 
Carruthers, Clement Price, and Whitney Strub have offered suggestion, feedback, and encouragement for things big and small related to the book. I count myself lucky to be working among a talented and committed group of scholars at Rutgers. Thanks also to Dean Philip Yeagle for his enthusiastic support of junior faculty at Rutgers-Newark and Christina Strasburger, administrator extraordinaire, for her everyday support and encyclopedic knowledge of everything Rutgers.

I spent two enormously productive years at Yale University as the Ethnicity, Race, and Migration Postdoctoral Fellow. The program director, Stephen Pitti, was effusive in his support and has become a valued mentor and friend. The manuscript workshop Steve organized for me back in the spring of 2009 came at a critical juncture that helped me revise and expand the book. Time spent with Matthew Frye Jacobson, Ned Blackhawk, Mary Lui, Alicia Schmidt Camacho, and Kariann Yokota also made my time at Yale a thoroughly enjoyable one. At the Yale workshop, Richard White and Mary Lui gave the first draft of the manuscript a close read and provided invaluable suggestions on how to move forward. Moon-Ho Jung also participated in that workshop and then took on the unenviable task of reading the penultimate version of the book. Moon has gone above and beyond as an interlocutor and friend, giving more than generously of his time and insights - and the book is far better for it.

I am also grateful to David Roediger, Eiichiro Azuma, Paul Kramer, Lisa Lowe, Gary Okihiro, Henry Yu, Matthew Frye Jacobson, John Findlay, Mrinalini Sinha, Paul Sue, Adam McKeown, Bruce Nelson, Eileen Boris, Ann Fabian, and Chris Friday for helpful conversation and feedback on specific chapters and writings related to the book. Excerpts from the book were first published as articles in the Journal of American History and the American Quarterly. I would like to thank the publishers and editors of these journals for their permission to reprint them here. At the University of California Press, I'd like to thank my editor Niels Hooper for seeing promise in the project early on and for his steady hand throughout. Thanks also to Kim Hogeland, Kate Warne, and Michael Bohrer-Clancy for their help in shepherding the book through the production process and to Heather McElwain for her expert copyediting.

Research for this book has taken me far and wide, and I'm grateful to numerous librarians and archivists who helped me locate materials at the University of Washington Special Collections; University of British Columbia Special Collections; National Archives and Records Administration in 
Washington, DC and the Pacific Northwest Region in Seattle, Washington; United States Immigration and Naturalization Service in Washington, DC; Library and Archives Canada in Ottawa, Ontario; Wing Luke Museum in Seattle, Washington; City of Vancouver Archives; Japanese-Canadian National Museum in Burnaby, British Columbia; Seattle Public Library; Simon Fraser University Archives in Burnaby, British Columbia; Densho Society in Seattle, Washington; Hoover Institution Archives in Stanford, California; and the British Library in London, England. A special thanks to Carla Rickerson, George Brandak, and Marian L. Smith for responding to my countless queries with patience and enthusiasm. I was fortunate to receive generous financial support from the Andrew W. Mellon Foundation, the Whitney and Betty MacMillan Center for International and Area Studies at Yale University, the Canadian Embassy, the American Historical Association, the Rutgers Faculty Research Grant Program, and the University of Chicago and the University of Connecticut History Departments.

I owe my greatest intellectual and professional debts to two people. I would probably not be a historian today (and this book wouldn't exist) if it weren't for Barbara Weinstein. Barbara was my first teacher, and it was her critically engaged teaching and scholarship that inspired me to be a historian in the first place. She also convinced me as an undergraduate that I would be happier (albeit poorer) as a history professor than as a lawyer. She was right on both accounts. Mae Ngai has contributed more to this book and my development as a scholar than anybody else. Having read and commented on the book more times than she cares to remember, Mae is probably happy (and relieved) to see the book finally in print. If there is anything interesting or smart in the book, it is probably due to her influence and model. It goes without saying any mistakes in analysis and interpretation are mine alone.

Finally, this book would not have been completed without the love of my family. My parents, Hyun Pyung Chang and Chun Young Rim, finally got used to their son reading books for a living though they had always preferred I take a "safer" professional route. I'm thankful for the big and small sacrifices they have made on my behalf. My sisters, Glory, Grace, Jin, and Min, my brothers-in-law Eugene Lee and Thomas Yu, and my father-in-law John Kim provided regular babysitting so I could work on the book, as well as timely diversions away from it. I am especially grateful to my mother-in-law Myong Hee Lee who took care of our infant twins on the days and nights I was commuting to Connecticut. As this book goes to press, I'm reminded of my late 
grandmother Kae Hee Lee who gave selflessly to everyone she encountered and was a model of human goodness. My children Kate and Carter didn't care one iota for the book, and for that, appa is grateful. My final and most important acknowledgment is saved for Laura Yon Kim who has known me and loved me far before this book (and hopefully long after it). Her partnership has meant more than she knows and so this book is dedicated to our life together. 


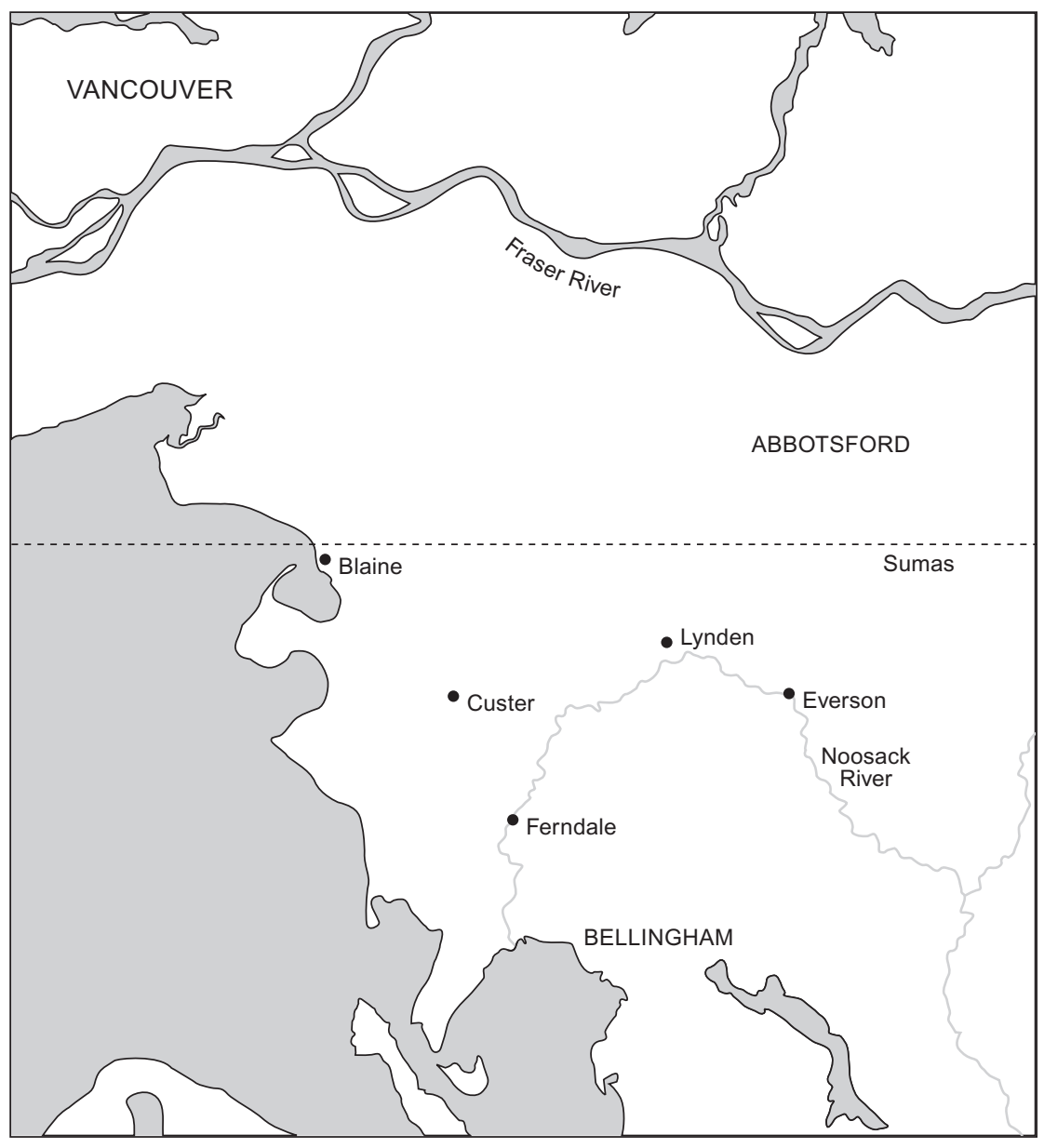

MAP I. The Puget Sound and Surrounding Areas. Drawn by Melissa Mok. 


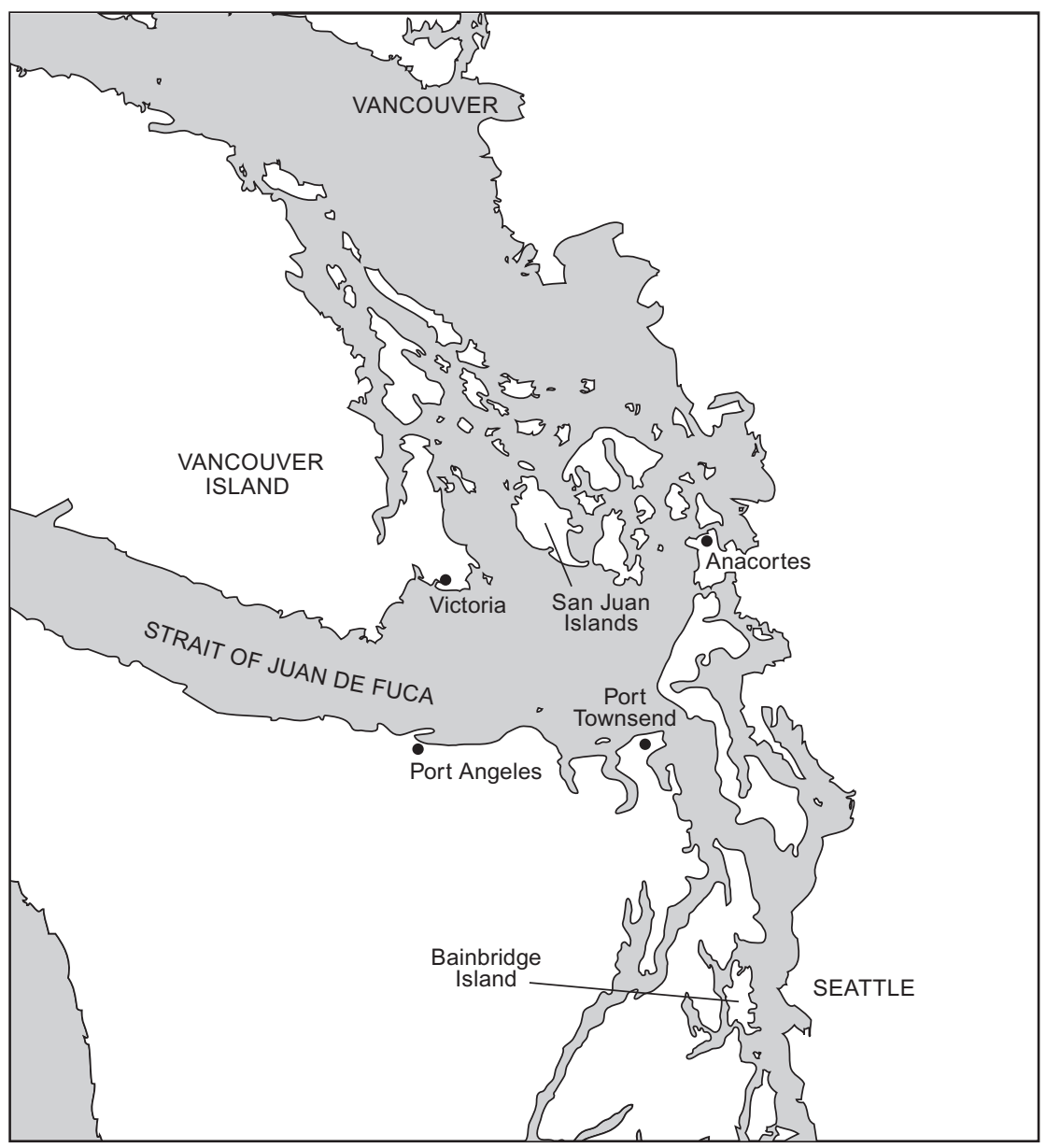

MAP 2. The Washington-British Columbia Boundary Region. Drawn by Melissa Mok. 